IJABBR-2017- eISSN: 2322-4827

International Journal of Advanced Biological and Biomedical Research 5(1) (2017) 27-34

Journal homepage: www.ijabbr.com

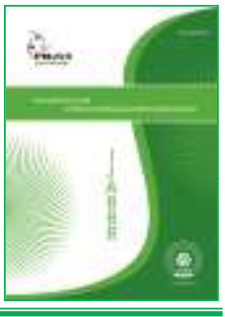

Research Article

DOI: 10.18869/IJABBR.2017.391

\title{
Effects of Inter and Intra Row Spacing on Growth, Yield and Yield Components of Roselle (Hibiscus Sabdariffa L.) at Wondo Genet, Southern Ethiopia
}

\author{
Basazinew Degu Gebremedin ${ }^{1}$, Bizuayehu Tesfaye Asfaw ${ }^{2}$ \\ ${ }^{1}$ Ethiopian Institute of Agricultural Research, Wondo Genet Agricultural Research Center, P.O. Box 198, Shashemene, \\ Ethiopia
}

${ }^{2}$ Hawassa University College of Agriculture, Department of Plant and Horticultural Science, Hawassa, Ethiopia

\section{ART I C L E IN F O}

\section{Article history:}

Received: 16 Jan 2017

Revised:21Feb 2017

Accepted: 22 Mar 2017

ePublished: 30 Apr 2017

\section{Key words:}

Hibiscus sabdariffa L.

Inter-row spacing

Intra-row spacing

Fresh calyx yield

Dry calyx yield

\section{A B S T R A C T}

Objective: A field experiment was conducted to assess the optimum inter- and intra-row spacing on growth, yield and yield component of roselle (Hibiscus sabdariffa L.) in 2014/15 cropping season at wondo Genet Agricultural Research Center experimental site (at wondo Genet station). Methods: Two inter-row spacings (60 and $90 \mathrm{~cm}$ ) and three intra-row spacings $(30,60$ and $90 \mathrm{~cm}$ ) were evaluated using two varieties, WGHibiscus-Jamaica and WG-Hibiscus-Sudan on a plot size of $3.6 \mathrm{~m}$ length $\mathrm{x} 4.2 \mathrm{~m}$ width. The experimental design was a randomized complete block design in factorial arrangement with 12 treatments in three replications. SAS (version 9) software was used to compute the analysis of variance. Results: The results revealed that varieties differed markedly in most of the studied parameters. Of the two varieties tested, variety WGHibiscus-Jamaican showed greater plant height, number of branches per plant, number of leaves/plant, leaf area, leaf area index, days to $50 \%$ flowering, days to $95 \%$ maturity, number of capsules/plant, fresh calyx yield/plant, dry calyx yield/plant, seed yield/plant, total number of capsules/ha, total fresh calyx yield/ha, total dry calyx yield/ha and total seed yield/ha. In contrast, variety WG-Hibiscus-Sudan matures earlier and had heavier 1000 seed weight than variety WG-Hibiscus-Jamaican. Number of capsules/plant, fresh and dry calyx yield/plant were influenced by interaction effects of variety; inter- and intra-row spacing. Moreover, fresh and dry calyx yield/plant, total fresh and dry calyx yield/ha were influenced by interaction effects of variety, inter- and intra-row spacing.

\section{Introduction}

Roselle (Hibiscus sabdariffa L.) is one of the most important annual medicinal shrub that belongs to the family Malvaceae and it is locally known as "Karkade". This genus has more than 300 species among which, two species of $H$. sabdariffa and $H$. altissimia have been mentioned as an important species (Chen et al., 2002). It is believed to be native of India and later introduced to
Malaysia where it is commonly cultivated and might have been carried at an early date to Africa (Morton, 1987). It is known in different countries by various common names, including roselle, razelle, sorrel, red sorrel, Jamaican sorrel, Indian sorrel, Guinea sorrel, sour-sour, and Queensland jelly plant (Mahadevan, 2009). In English-speaking countries it is known as roselle, Jamaican sorrel, red sorrel, Indian sorrel, rozelle hemp, natal sorrel and rosella. The Japanese name is rohzelu;

${ }^{*}$ Corresponding Author: Basazinew Degu Gebremedin, Ethiopian Institute of Agricultural Research, Wondo Genet Agricultural Research Center, P.O. Box 198, Shashemene, Ethiopia 
also sabdriqa or lalambari in Urdu (Kays, 2011); and lalambari, patwa or laalambaar in Hindi (Kays, 2011). Roselle is an important cash crop in Western Sudan, particularly in Northern Kordofan State, especially in Elrahad and Um-Rawaba areas (El Naim et al., 2012).

The calyces are widely used to prepare herbal drink, cold and warm beverages, and for making jams and jellies (Tsai et al., 2002). In Africa, they are frequently cooked as a side dish and eaten with pulverized peanuts for stewing as sauce, for making a fine-textured sauce or juice (zobo), syrup, jam, marmalade, relish, chutney or jelly. The seeds are somewhat bitter but have been grounded to a meal for human food in Africa and have also been roasted as a substitute for coffee (Seiyaboh et al., 2013). Red calyces (based on $100 \mathrm{~g}$ dry weight) contain $6.4 \%$ protein, 79.3 $\%$ carbohydrates, $5.1 \%$ fat, $2.7 \%$ crude fiber, and $6.5 \%$ ash (Nnam and Onyeke, 2003). Roselle is one of the most important and popular medicinal plant which has several properties. The leaves are emollient and are much used in Guinea as a diuretic, refrigerant and sedative (Anhwange et al., 2006) and used to sour the curry or "dal" preparation in Bangladesh as well as the young leaves are used as vegetable (Patil, 2004). The calyx, boiled in water is used as a drink in bilious attacks (Perry, 1980) and has also shown to lower blood pressure (McKay, 2010). The seeds of roselle are used as diuretic, laxative, tonic (Duke, 1985) and to treat debility (Perry, 1980).

In a study on the effect of sowing date and plant density on yield and agronomical traits of roselle in Zabol, Iran, it was reported that the increase in density from 4 to 8 plants $/ \mathrm{m}^{2}$, significantly decrease sepal weight and capsule number per plant, but capsule number per $\mathrm{m}^{2}$, sepal to capsule weight ratio, sepal yield and biological yield per unit area increased with the increase in plant density (Mir et al., 2011). Gholam and Moosavi (2012) studied the effect of sowing date and plant density on yield and yield components of roselle in Birjan, Iran, it was reported that the increase in density from 8 to 13.3 plants $/ \mathrm{m}^{2}$, fruit number per plant, sepal yield per fruit and plant and single biomass decreased significantly by 29.8, 24.4, 39.1, 55.4 and $33.6 \%$, respectively, but fruit number $/ \mathrm{m}^{2}$ increased by $18.2 \%$.

In Ethiopia roselle is mainly used to produce healthy juice and herbal tea with full of flavor and tart, due to its high contents of vitamin $\mathrm{C}$ and anthocyanins that are found in the calyces. Roselle is predominantly produced by small scale farmers in their homestead garden. Ethiopia has a suitable environment for the production of roselle. But, there are limited findings regarding the modern production technology and to increase productivity to attract the industries or enterprises which are engaged in production and processing of roselle. This is due to lack of knowledge about the crop and limited supply of the crop products. Proper production technology is necessary for productivity of roselle to supply quality product to local or international markets, pharmaceuticals and beverage industries. The crop is produced in traditional management practices by small scale-farmers, depending on rainfall and poor agronomic practices. The main gap in production of the crop is poor agronomic practice such as improper spacing. Considering the enormous benefits of the roselle crop it is necessary to promote its growth and performance in terms of marketable and edible yields by growing it at an optimum spacing. The main yieldlimiting factors are information or skill gap on how to produce this crop. Therefore, the study had the following objectives:

\section{General objective}

To contribute towards improved yield of roselle produced in Ethiopia.

\section{Specific objectives}

To measure growth, yield and yield components of roselle at different inter- and intra-row spacing.

To evaluate the interaction between and within inter-, intra-row spacing and varieties in relation to yield and yield components.

\section{Materials and methods}

The experiment was conducted at Wondo Genet Agricultural Research Center experimental site in Southern Ethiopia during 2014/2015 cropping season. Wondo Genet is located between $7^{\circ} 19^{\prime} \mathrm{N}$ latitude and $38^{\circ} 38^{\prime} \mathrm{E}$ longitude; it is found at an altitude of 1780 m.a.s.l (meter above sea level) and receives mean annual rainfall of $1128 \mathrm{~mm}$ with minimum and maximum temperature of $11{ }^{\circ} \mathrm{C}$ and $26^{\circ} \mathrm{C}$, respectively. The soil textural class of the experimental area is sandy loam with $\mathrm{pH}$ of 6.4 (Abayneh et al, 2006).

The seeds of the two varieties; namely, WG-HibiscusJamaica (V1) and WG-Hibiscus-Sudan (V2) were sown on spot directly on the experimental field at two inter-row spacings: 60 and $90 \mathrm{~cm}$ and three intra-row spacings 30 , 60 and $90 \mathrm{~cm}$ after the land prepared well. The experiment was laid out as in a factorial Randomized Complete Block Design (RCBD) with three replications. The plot size was $15.12 \mathrm{~m}^{2}$ (3.6 m length $\mathrm{x} 4.2 \mathrm{~m}$ width). There were a total of eighteen experimental units for each variety. The distance between each plot and 
replication was $1 \mathrm{~m}$ and $1.5 \mathrm{~m}$, respectively. Sowing was done on $18^{\text {th }}$ of September, 2014. Thinning was done progressively for the seedlings from spot sowing. The first thinning was done 10 days after sowing, to obtain 2 plants per spot. The final thinning was done 17 days after sowing, to have one plant per spot. The field was weeded twice a month starting from seeding until it was established well, the first one after two weeks from sowing and the second at four weeks later. And also the remaining weeding practices, hoeing and watering were made as required.

Data on days to $50 \%$ flowering, days to $95 \%$ physiological maturity, plant height, number of branches/plant, number of leaves/plant, leaf area, leaf area index, number of capsules/plant, fresh calyx yield/plant, dry calyx yield/plant, seed yield/plant, 1000 seed weight, total number of capsules/ha, total fresh calyx yield/ha, total dry calyx yield/ha, total seed yield/ha and harvest index. To statically analyze the differences in characters caused by genotypic and spacing differences, five randomly selected samples were taken from each plot.

Mean values of all data for all characters measured were subjected to analysis of variance (ANOVA) using General Linear Model (GLM), statistical analysis software program (SAS inst., 2002). The Tukey's Studentized Range (HSD) Test was used to compare the mean separations at $5 \%$ probability level.

\section{Results and discussion Variety}

Variety had a significant effect on phonological and growth attributes (Table 1) as well as on yield attributes (Table 2). As the result revealed that, except thousand seed weight variety WG-Hibiscus-Jamaica was superior in all parameters than variety WG-Hibiscus-Sudan.

\section{Spacing \\ Inter-row spacing}

Inter-row spacing had a significant effect on number of leaves/plant, leaf area index (Table 1), number of capsules/ha, fresh and dry calyx yield/ha (Table 2).

\section{Intra-row spacing}

Intra-row spacing had a significant effect on days to $50 \%$ flowering, number of leaves/plant, leaf area, leaf area index (Table 1), number of capsules/ha, fresh and dry calyx yield/ha and dry seed yield/ha (Table 2).

\section{Interactions}

\section{Days to $\mathbf{5 0 \%}$ flowering}

In the three way interaction the result revealed that, the highest number of days to $50 \%$ flowering was recorded at interaction of variety WG-Hibiscus-Jamaica, inter-row spacing of $60 \mathrm{~cm}$ and intra-row spacing of $90 \mathrm{~cm}$; whereas, the lowest number of days to $50 \%$ flowering was recorded at interaction of variety WG-HibiscusSudan, inter-row spacing of $60 \mathrm{~cm}$ and intra-row spacing of $30 \mathrm{~cm}$ and also at interaction of variety WG-HibiscusSudan, inter-row spacing of $90 \mathrm{~cm}$ and intra-row spacing of $30 \mathrm{~cm}$ (Table 3). This could be due to the fact that, at wider spacing plant population density was less; hence, the competition for light, nutrients and space was less thereby delay in days to $50 \%$ flowering. Similar result was reported by Alessi et al. (1977) on sunflower. Contrasting results was reported by El Naim et al. (2012) who showed that plant population density had no significant effect on time to $50 \%$ flowering on roselle.

\section{Plant height}

The highest plant height was recorded at interaction of variety WG-Hibiscus-Jamaica, inter-row spacing of $60 \mathrm{~cm}$ and intra-row spacing of $30 \mathrm{~cm}$; while, the least value was recorded at interaction of variety WG-HibiscusSudan, inter-row spacing of $90 \mathrm{~cm}$ and intra-row spacing of $60 \mathrm{~cm}$ (Table 3). The highest plant height was obtained at planting of both varieties on closer inter- and closest intra-row spacing combination. This could be due to high competition of plants to light, nutrients, water and space. Supporting evidences were reported by Talukder et al. (2003) on okra, El Naim and Jabereldar (2010) on cowpea, Ramos et al. (2011) on roselle, Wenyonu et al. (2011) on okra, Zewdinesh et al. (2011) on Artemisia annua and Mushayabasa et al. (2014) on okra who stated that an increase in planting population markedly would increase plant height. The tallest plants produced by the most densely populated plants might be attributed to the competition for light and other growth resources among the plants that were crowded at the closer plant spacing (Maurya et al., 2013). Contrasting result obtained by El Naim et al. (2012) who showed that crop density had no significant effect on plant height of roselle.

\section{Fresh calyx yield/plant}

The highest fresh calyx yield/plant was recorded at interaction of variety WG-Hibiscus-Jamaica, inter-row spacing of $90 \mathrm{~cm}$ and intra-row spacing of $60 \mathrm{~cm}$; while, the lowest value was recorded at interaction of variety WG-Hibiscus-Sudan, inter-row spacing of $90 \mathrm{~cm}$ and 
intra-row spacing of $60 \mathrm{~cm}$ (Table 3). Fresh calyx yield/plant increased by decreasing plant population density in WG-Hibiscus-Jamaica due to less competition of plants for light, nutrients and space. But in case of WGHibiscus-Sudan, fresh calyx yield/plant increased linearly by decreasing inter-row spacing and by increasing of intra-row spacing. This could be due to favorable growth conditions of inter- and intra-row spacing combinations for maximum fresh calyx development

\section{Dry calyx yield/plant}

The highest dry calyx yield/plant was recorded at interaction of variety WG-Hibiscus-Jamaica with interrow spacing of $90 \mathrm{~cm}$ and intra-row spacing of $60 \mathrm{~cm}$; whereas, the lowest dry calyx yield/plant was recorded at interaction of variety WG-Hibiscus-Sudan with interrow spacing of $90 \mathrm{~cm}$ and intra-row spacing of $90 \mathrm{~cm}$ (Table 3). Dry calyx yield/plant increased by decreasing of plant population density due to less competition of plants for light, nutrients, water and space in WGHibiscus-Jamaica. But in case of WG-Hibiscus-Sudan, dry calyx yield/plant increased linearly by decreasing of inter-row spacing and by increasing of intra-row spacing. This could be due to favorable growth conditions of inter- and intra-row spacing combinations for maximum dry calyx yield production.

\section{Thousand seed weight}

The highest 1000 seed weight was recorded at interaction of variety WG-Hibiscus-Sudan, inter-row spacing of $90 \mathrm{~cm}$ and intra-row spacing of $90 \mathrm{~cm}$; while, the lowest value was recorded at interaction of variety WG-Hibiscus-Jamaica, inter-row spacing of $60 \mathrm{~cm}$ and intra-row spacing of $60 \mathrm{~cm}$ (Table 4). 1000-seed weight increased at lowest plant population density in WGHibiscus-Sudan due to the fact that reduced competition of plants for light, water and nutrient could able to produce highest 1000 -seed weight. But in case of WGHibiscus-Jamaica, 1000 seed weight increased at the prescribed spacing. This could be due to favorable growth conditions of the spacing for maximum seed weight. Contrasting results were reported by Jakusko et al. (2013) on sesame and Yayeh et al. (2014) on field pea.

Table 1: Effects of variety, inter- and intra-row spacing on the phenological and growth attributes of roselle varieties planted at Wondo Genet, in 2014 cropping season

\begin{tabular}{|c|c|c|c|c|c|c|c|}
\hline \multirow{2}{*}{$\begin{array}{l}\text { Treatments and } \\
\text { statistics }\end{array}$} & \multicolumn{7}{|c|}{ Mean growth and phenological attributes } \\
\hline & DFPF & DNFPM & $\mathrm{PH}(\mathrm{cm})$ & NBPP & NLPP & $\mathrm{LA}\left(\mathrm{m}^{2}\right)$ & LAI \\
\hline Variety & & & & & & & \\
\hline $\begin{array}{l}\text { WG-Hibiscus- } \\
\text { Jamaica }\end{array}$ & $122.3 a$ & 204.1a & $123.36 \mathrm{a}$ & $17.99 \mathrm{a}$ & $830.65 a$ & $0.36 \mathrm{a}$ & $2.59 \mathrm{a}$ \\
\hline $\begin{array}{l}\text { WG-Hibiscus- } \\
\text { Sudan }\end{array}$ & $70.92 b$ & $149.69 b$ & $80.37 \mathrm{~b}$ & $7.66 \mathrm{~b}$ & $154.37 \mathrm{~b}$ & $0.1 \mathrm{~b}$ & $2.22 \mathrm{~b}$ \\
\hline $\begin{array}{l}\mathrm{CD}_{0.05} \\
\text { Inter-RS }(\mathrm{cm})\end{array}$ & 0.64 & 4.37 & 7.58 & 1.29 & 56.01 & 0.04 & 0.19 \\
\hline 60 & 96.48 & 176.61 & 103.98 & 12.85 & $528.08 \mathrm{a}$ & 0.24 & $2.53 a$ \\
\hline 90 & 96.73 & 177.19 & 99.76 & 12.81 & $456.94 b$ & 0.22 & $2.28 b$ \\
\hline $\begin{array}{l}\mathrm{CD}_{0.05} \\
\text { Intra-RS (cm) }\end{array}$ & ns & ns & ns & ns & 56.01 & ns & 0.19 \\
\hline 30 & $95.50 \mathrm{c}$ & 175.92 & 104.02 & 12.39 & $346.73 b$ & $0.15 b$ & $2.90 \mathrm{a}$ \\
\hline 60 & $96.63 \mathrm{~b}$ & 176.62 & 97.03 & 13.12 & $549.64 \mathrm{a}$ & $0.25 a$ & $2.35 b$ \\
\hline 90 & $97.69 \mathrm{a}$ & 178.15 & 104.55 & 12.97 & $581.16 a$ & $0.30 \mathrm{a}$ & $1.97 \mathrm{c}$ \\
\hline $\mathrm{CD}_{0.05}$ & 0.95 & ns & ns & ns & 83.09 & 0.06 & 0.28 \\
\hline CV (\%) & 0.96 & 3.57 & 10.77 & 14.50 & 16.45 & 23.94 & 11.35 \\
\hline
\end{tabular}

Means followed by the same letter in the same column are not significantly different at 5\% probability level using Tukey`s Studentized Range (HSD) Test. ns= non significant at $5 \%$ probability level, RS= Row spacing, DEPF= Days to $50 \%$ flowering, DNFPPM= Days to $95 \%$ physiological maturity, $\mathrm{PH}=$ Plant height, NBPP= Number of branches/plant, NLPP= Number of leaves/plant, LA= Leaf area, LAI= Leaf area index and $\mathrm{CD}=$ Critical difference

\section{Total fresh calyx yield/ha}

The highest total fresh calyx yield/ha was recorded at interaction of variety WG-Hibiscus-Jamaica, inter-row spacing of $60 \mathrm{~cm}$ and intra-row spacing of $30 \mathrm{~cm}$; whereas, the lowest value was recorded at interaction of variety WG-Hibiscus-Sudan, inter-row spacing of $90 \mathrm{~cm}$ and intra-row spacing of $90 \mathrm{~cm}$ (Table 4). In closest spacing $(60 \mathrm{~cm} \times 30 \mathrm{~cm})$ total fresh calyx yield/ha was 
increased by $54.85 \%$ in WG-Hibiscus-Jamaica and $86.29 \%$ in WG-Hibiscus-Sudan as compared to widest spacing $(90 \mathrm{~cm} \times 90 \mathrm{~cm})$. Total fresh calyx yield/ha increased by increasing plant population density per unit area. This could be due to the fact that high population density per unit area attributed to the increase in total fresh calyx yield/ha.

Table 2: Effects variety, inter- and intra-row spacing on yield attributes of roselle varieties planted at Wondo Genet, in 2014 cropping season

\begin{tabular}{lllll}
\hline $\begin{array}{l}\text { Treatments and } \\
\text { Statistics }\end{array}$ & NCPH & FCYPH $(\mathrm{kg})$ & DCYPH $(\mathrm{kg})$ & SYPH $(\mathrm{t})$ \\
\hline Variety & & & & \\
WG-Hibiscus-Jamaica & $3054187 \mathrm{a}$ & $9258.6 \mathrm{a}$ & $1019.76 \mathrm{a}$ & $1.56 \mathrm{a}$ \\
WG-Hibiscus-Sudan & $1496527 \mathrm{~b}$ & $4170.7 \mathrm{~b}$ & $458.80 \mathrm{~b}$ & $0.79 \mathrm{~b}$ \\
Mean & 2275357 & 6714.65 & 739.28 & 1.18 \\
CD 0.05 & 493114 & 1141.5 & 149.27 & 0.27 \\
$\quad$ Inter-RS (cm) & & & & \\
60 & $2584845 \mathrm{a}$ & $7817.4 \mathrm{a}$ & $865.78 \mathrm{a}$ & 1.30 \\
90 & $1965869 \mathrm{~b}$ & $5611.8 \mathrm{~b}$ & $612.77 \mathrm{~b}$ & 1.05 \\
Mean & 2275357 & 6714.6 & 739.28 & 1.18 \\
CD 0.05 & 493114 & 1141.5 & 149.27 & Ns \\
$\quad$ Intra-RS (cm) & & & & \\
30 & $3091832 \mathrm{a}$ & $8983.7 \mathrm{a}$ & $1025.42 \mathrm{a}$ & $1.61 \mathrm{a}$ \\
60 & $2247463 \mathrm{~b}$ & $6241.8 \mathrm{~b}$ & $671.78 \mathrm{~b}$ & $1.18 \mathrm{~b}$ \\
90 & $1486775 \mathrm{c}$ & $4918.4 \mathrm{~b}$ & $520.63 \mathrm{~b}$ & $0.73 \mathrm{c}$ \\
Mean & 2275357 & 6714.6 & 739.28 & 1.17 \\
CD 0.05 & 731544 & 1693.4 & 221.45 & 0.4 \\
\hline CV $(\%)$ & 31.35 & 24.59 & 29.21 & 33.13 \\
\hline
\end{tabular}

Means followed by the same letter in the same column are not significantly different at $5 \%$ probability level using Tukey`s Studentized Range (HSD) Test. ns= non significant at $5 \%$ probability level, RS= Row spacing, NCPH= Total number of capsules/ha, FCYPH= Total fresh calyx yield/ha, DCYPH= Total dry calyx yield/ha, SYPH= Seed yield/ha and CD= Critical difference

\section{Total dry calyx yield/ha}

The highest total dry calyx yield/ha was recorded at interaction of variety WG-Hibiscus-Jamaica, inter-row spacing of $60 \mathrm{~cm}$ and intra-row spacing of $30 \mathrm{~cm}$; while, the lowest value was recorded at interaction of variety WG-Hibiscus-Sudan, inter-row spacing of $90 \mathrm{~cm}$ and intra-row spacing of $90 \mathrm{~cm}$ (Table 4). In closest spacing total dry calyx yield/ha was increased by $61.16 \%$ in WGHibiscus-Jamaica and $87.62 \%$ in WG-Hibiscus-Sudan as compared to widest spacing $(90 \mathrm{~cm} \times 90 \mathrm{~cm})$. This could be due to the fact that high population density per unit area attributed to the increase in total dry calyx yield/ha. 
Table 3: Interaction effects of variety, inter- and intra-row spacing on days to $50 \%$ flowering, plant height, fresh and dry calyx yield/plant of roselle varieties planted at Wondo Genet, in 2014 cropping season

\begin{tabular}{|c|c|c|c|c|}
\hline \multirow[b]{2}{*}{ Treatments and statistics } & \multicolumn{4}{|c|}{ Mean phenological, growth and yield attributes } \\
\hline & DFPF (DAS) & PH (cm) & FCYPP (g) & DCYPP (g) \\
\hline Variety*inter-RS*intra-RS & & & & \\
\hline $\mathrm{V} 1 * 60 \mathrm{~cm} * 30 \mathrm{~cm}$ & $121 \mathrm{~b}$ & $140.47 \mathrm{a}$ & $258.45 b c$ & $29.69 \mathrm{bc}$ \\
\hline $\mathrm{V} 1 * 60 \mathrm{~cm} * 60 \mathrm{~cm}$ & $121 \mathrm{~b}$ & $114.76 \mathrm{abc}$ & $258.93 \mathrm{bc}$ & $29.58 \mathrm{bc}$ \\
\hline $\mathrm{V} 1 * 60 \mathrm{~cm} * 90 \mathrm{~cm}$ & $124.9 \mathrm{a}$ & 125.69ab & 447.64ab & $23.80 \mathrm{~cd}$ \\
\hline $\mathrm{V} 1 * 90 \mathrm{~cm} * 30 \mathrm{~cm}$ & $121 \mathrm{~b}$ & $104.33 \mathrm{bcd}$ & $210.43 c$ & $23.33 \mathrm{~cd}$ \\
\hline$V 1 * 90 \mathrm{~cm}^{*} 60 \mathrm{~cm}$ & $123 a b$ & 119.78ab & $563.69 a$ & $61.82 \mathrm{a}$ \\
\hline $\mathrm{V} 1 * 90 \mathrm{~cm} * 90 \mathrm{~cm}$ & $122.9 \mathrm{ab}$ & $135.11 \mathrm{ab}$ & $500.22 \mathrm{a}$ & 49.59ab \\
\hline $\mathrm{V} 2 * 60 \mathrm{~cm} * 30 \mathrm{~cm}$ & $70 \mathrm{c}$ & $86.07 \mathrm{cde}$ & $155.48 \mathrm{c}$ & $16.69 \mathrm{~cd}$ \\
\hline $\mathrm{V} 2 * 60 \mathrm{~cm} * 60 \mathrm{~cm}$ & $71 \mathrm{c}$ & $84.13 \mathrm{cde}$ & $169.52 \mathrm{c}$ & $16.97 \mathrm{~cd}$ \\
\hline $\mathrm{V} 2 * 60 \mathrm{~cm} * 90 \mathrm{~cm}$ & $71 \mathrm{c}$ & $72.73 \mathrm{de}$ & $201.54 \mathrm{c}$ & $23.8 \mathrm{~cd}$ \\
\hline $\mathrm{V} 2 * 90 \mathrm{~cm} * 30 \mathrm{~cm}$ & 70c & $85.20 \mathrm{cde}$ & $115.63 c$ & $15.11 \mathrm{~cd}$ \\
\hline $\mathrm{V} 2 * 90 \mathrm{~cm} * 60 \mathrm{~cm}$ & $71.5 c$ & $69.43 \mathrm{e}$ & $108.31 \mathrm{c}$ & $10.19 \mathrm{~cd}$ \\
\hline $\mathrm{V} 2 * 90 \mathrm{~cm} * 90 \mathrm{~cm}$ & $72 \mathrm{c}$ & 84.67cde & $89.48 c$ & $8.6 \mathrm{~d}$ \\
\hline Mean & 96.61 & 101.86 & 256.61 & 25.76 \\
\hline $\mathrm{CD}_{0.05}$ & 2.76 & 32.58 & 194.44 & 20.32 \\
\hline CV $(\%)$ & 0.96 & 10.77 & 25.51 & 24.62 \\
\hline
\end{tabular}

Means followed by the same letter in the same column are not significantly different at $5 \%$ probability level using Tukey`s Studentized Range (HSD) Test. RS= Row spacing, DEPF= Days to $50 \%$ flowering (days after sowing), PH= Plant height, FCYPP= Fresh calyx yield/plant, DCYPP= Dry calyx yield/plant and CD= Critical difference.

Table 4: Interaction effects of variety, inter- and intra-row spacing on 1000 seed weight, total fresh calyx yield/ha and dry calyx yield/ha of roselle varieties planted at Wondo Genet, in 2014 cropping season

\begin{tabular}{|c|c|c|c|}
\hline \multirow[b]{2}{*}{ Treatments and statistics } & \multicolumn{3}{|c|}{ Mean yield attributes } \\
\hline & TSW (g) & FCYPH (kg) & DCYPH (kg) \\
\hline \multicolumn{4}{|l|}{ Variety*inter-RS*intra-RS } \\
\hline $\mathrm{V} 1 * 60 \mathrm{~cm}^{*} 30 \mathrm{~cm}$ & $21.93 \mathrm{~b}$ & $14359 a$ & 1649.3a \\
\hline $\mathrm{V} 1 * 60 \mathrm{~cm} * 60 \mathrm{~cm}$ & $21.73 \mathrm{~b}$ & $7193 \mathrm{bcd}$ & $819.9 \mathrm{bcd}$ \\
\hline $\mathrm{V} 1 * 60 \mathrm{~cm} * 90 \mathrm{~cm}$ & $22.85 b$ & $8275 \mathrm{bcd}$ & $886.5 b c$ \\
\hline $\mathrm{V} 1 * 90 \mathrm{~cm} * 30 \mathrm{~cm}$ & $23.27 \mathrm{~b}$ & $8350 \mathrm{bcd}$ & $925.9 b c$ \\
\hline $\mathrm{V} 1 * 90 \mathrm{~cm} * 60 \mathrm{~cm}$ & $23.40 \mathrm{~b}$ & 10893ab & $1196.4 \mathrm{ab}$ \\
\hline $\mathrm{V} 1 * 90 \mathrm{~cm} * 90 \mathrm{~cm}$ & $21.98 \mathrm{~b}$ & 6483bcde & 640.6bcde \\
\hline $\mathrm{V} 2 * 60 \mathrm{~cm} * 30 \mathrm{~cm}$ & $36.64 a$ & $8638 \mathrm{bc}$ & $927.0 \mathrm{bc}$ \\
\hline $\mathrm{V} 2 * 60 \mathrm{~cm} * 60 \mathrm{~cm}$ & $37.08 \mathrm{a}$ & 4709cdef & $471.3 \mathrm{cde}$ \\
\hline $\mathrm{V} 2 * 60 \mathrm{~cm}^{*} 90 \mathrm{~cm}$ & $36.21 \mathrm{a}$ & 3732def & $440.7 \mathrm{cde}$ \\
\hline $\mathrm{V} 2 * 90 \mathrm{~cm} * 30 \mathrm{~cm}$ & $37.45 \mathrm{a}$ & $4588 \mathrm{cdef}$ & $599.5 b c d e$ \\
\hline $\mathrm{V} 2 * 90 \mathrm{~cm} * 60 \mathrm{~cm}$ & $36.11 \mathrm{a}$ & $2173 \mathrm{ef}$ & 199.5de \\
\hline $\mathrm{V} 2 * 90 \mathrm{~cm} * 90 \mathrm{~cm}$ & $38.18 \mathrm{a}$ & $1184 \mathrm{f}$ & $114.8 \mathrm{e}$ \\
\hline Mean & 29.74 & 6714.75 & 739.28 \\
\hline $\mathrm{CD} 0.05$ & 3.28 & 4904.3 & 641.33 \\
\hline CV (\%) & 3.71 & 24.59 & 29.21 \\
\hline
\end{tabular}

Means followed by the same letter in the same column are not significantly different at 5\% probability level using Tukey`s Studentized Range (HSD) Test. RS= Row spacing, TSW= 1000 seed weight, FCYPH= Total fresh calyx yield/ha, DCYPH= Total dry calyx yield/ha and $\mathrm{CD}=$ Critical difference

\section{Conclusion}

The present study demonstrated that, the highest total fresh and dry calyx yield/ha were recorded when WGHibiscus-Jamaica and WG-Hibiscus-Sudan were planted at inter-row spacing of $60 \mathrm{~cm}$ and intra-row spacing of 30 $\mathrm{cm}$. When planting WG-Hibiscus-Jamaica at inter-row spacing of $60 \mathrm{~cm}$ and intra-row spacing of $30 \mathrm{~cm}(60 \mathrm{~cm} \mathrm{x}$ $30 \mathrm{~cm}$ ) total fresh and dry calyx yield/ha increased by
54.85 and $61.16 \%$, respectively as compared to planting at inter-row spacing of $90 \mathrm{~cm}$ and intra-row spacing of 90 $\mathrm{cm}(90 \mathrm{~cm} \times 90 \mathrm{~cm})$. When planting WG-Hibiscus-Sudan at inter-row spacing of $60 \mathrm{~cm}$ and intra-row spacing of 30 $\mathrm{cm}(60 \mathrm{~cm} \times 30 \mathrm{~cm})$ total fresh and dry calyx yield/ha increased by 86.29 and $87.62 \%$, respectively as compared to planting at inter-row spacing of $90 \mathrm{~cm}$ and intra-row spacing of $90 \mathrm{~cm}(90 \mathrm{~cm} \times 90 \mathrm{~cm})$. Based on 
this result, $60 \mathrm{~cm}$ inter-row spacing with $30 \mathrm{~cm}$ intra-row spacing is highly recommended for the highest total fresh and dry calyx yield/ha at Wondo Genet and at a place where having similar agro-ecologies to Wondo Genet.

\section{Acknowledgment}

First of all, I would like to thank the Almighty God for his perpetual help and unreserved gift for all the achievements. I would like to give my deepest thank to the Ethiopian Institute of Agricultural Research, Wondo Genet Agricultural Research Center for providing me with the chance to do this research. My special appreciation also goes to my wife W/ro Endalamaw Shewaye who helped me a lot while carrying out the experiment and for her decisive assistance during this work. Last but not least, my heartfelt appreciation also goes to all of my lovely parents, WGARC staffs in general for their unbounded moral support and encouragement during the study period.

\section{References}

Abayneh Esayas, DemekeTafesse, Ashenafi Ali (2006). Soils of Wondo Genet Agricultural Research Center. National Soil Research Center, 67 pp.

Alessi J, Power JF, Zimmerman DC (1977). Sun flower yield and water use as influenced by planting date.

Anhwange BA, Ajibola VO, Okibe FG (2006). Nutritive value and antinutritional factors in Hibiscus sabdariffa. J. Fish. Int. 2:73-76.

Chen CC, Hsu JD, Wang SF, Chiang HC, Yang MY, Kao ES (2002). Hibiscus Sabdariffa extract inhibits the development of atherosclerosis in cholesterol-fed rabbits. J. Agric. food Chem., 5: 5472-5477.

Duke JA, Ayensu ES (1985). Medicinal plants of China. 2 vol. Reference Publications, Inc., Algonac, MI, USA.

El Naim AM, Jabereldar AA (2010). Effect of plant density and cultivar on growth and yield of cowpea (VignaunguiculataL.Walp). Australian Journal of Basic and Applied Sciences, 4(8): 3148-3153

El Naim AM, Khaliefa EH, Ibrahim KA, Ismaeil FM, Zaied MB (2012).Growth and Yield of Roselle (Hibiscus sabdariffa L.) as Influenced by Plant Population in Arid Tropic of Sudan under Rain-fed. International Journal of Agriculture and Forestry, 2(3): 88-91
Gholam S and Moosavi R (2012).The effect of sowing date and plant density on yield and yield components of roselle. J. Med. Plants Res. 6(9): 1627-1632

Jakusko BB, Usman BD, Mustapha AB (2013).Effect of row spacing on growth and yield of Sesame (Sesamumindicum L.) in Yola, Adamawa State, Nigeria.IOSR Journal of Agriculture and Veterinary Science (IOSR-JAVS). 2: 36-39

Kays SJ (2011). Cultivated vegetables of the world: A multilingual onomasticon. University of Georgia.Wageningen Academic Publishers, The Netherlands, 184 pp.

Mahadevan N, Shivali KP (2009). Hibiscus sabdariffaLinn: An overview. Natural Product Radiance, 8: 77-83.

Maurya RP, Bailey JA, Chandler JSA (2013).Impact of plant spacing and picking interval on the growth, fruit quality and yield of okra (Abelmoschusesculentus (L.)Moench). American Journal of Agriculture and Forestry 1(4): 48-54.

McKay DL, Chen CYO, Saltzman E, Blumberg JB (2010). Hibiscus sabdariffaL. tea (tisane) lowers blood pressure in pre-hypertensive and mildly hypertensive adults. Journal of Nutrition 140: 298-303.

Mir BG, Ravan S, Asgharipour M (2011). Effects of plant density and sowing date on yield and yield components of Hibiscus sabdariffa in Zabol region. Adv. Environ. Biol., 5(6): 1156-1161.

Morton JF (1987). Roselle. In Fruits of Warm Climates, ed. C.F. Dowling Jr. Media Inc., Greensboro, NC, USA, pp. 281- 286.

Mushayabasa T, Kona D, Gama R (2014). Yield and fruit quality of okra (Abelmoschusesculentus L. Moench) in response to plant density. Int. J. Biosci.5(1): 449-454.

Nnam NM, Onyeke NG (2003). Chemical composition of two varieties of sorrel (Hibiscus sabdariffaL.), calyces and the drinks made from them. Plant Foods Human Nutrition 58:1-7.

Patil KB (2004). Effect of various seed rates on yield of leafy vegetable sorrel. J. Soil Crop. 14(2): 461-462.

Perry IM (1980). Medicinal plants of East and Southeast Asia. MIT Press, Cambridge. 
SAS inst. (2002). SAS (Statistical Analysis System). 1996. SAS/STAT. Guide Version 9. SAS, Institute Inc. Raleigh, North Carolina: USA.

Seiyaboh EI, Oku IY, Odogbo OM (2013). Isolation and Identification Of Food-Borne Micro Flora From Zobo (A Nigerian Drink) Prepared From The Calyces Of Hibiscus Sabdariffa L. (Malvaceae). The International Journal of Engineering and Science (IJES) 2: 2319 - 1805.

Talukder MAH, Mannaf MA, Alam MK, Salam MA, MMU (2003). Influence of sowing time, plant spacing and picking interval on the growth and yield of okra. Pakistan Journal of Biological Sciences, 6(18): 1626-1630.

Tsai PJ, McIntosh J, Pearce P, Camden B, Jordan BR (2002). Anthocyanin and antioxidant capacity in Roselle (Hibiscus sabdariffaL.) extract. Food Research International. 35: 351-356.

How to cite this manuscript: Basazinew Degu Gebremedin, Bizuayehu Tesfaye Asfaw. Effects of Inter and Intra Row Spacing on Growth, Yield and Yield Components of Roselle (Hibiscus Sabdariffa L.) at Wondo Genet, Southern Ethiopia. International Journal of Advanced Biological and Biomedical Research 5(1), 2017, 27-34. DOI: 10.18869/IJABBR.2017.391.
Yayeh Bitew, Fekremariam Asargew, Oumer Beshir (2014). Effect of Plant Spacing on the Yield and Yield Component of Field Pea (PisumSativum L.) at Adet, North Western Ethiopia.Agriculture, Forestry and Fisheries. 3(5): 368-373.

Zewdinesh Damtew, Bizuayehu Tesfaye, Daniel Bisrat (2011).Leaf, Essential Oil and Artemisinin Yield of Artemisia (Artemisia annua L.) As Influenced by Harvesting Age and Plant Population Density. World J. Agric. Sci., 7(4): 404-412. 